ISSN 1412-2936

EISSN 2549-7308

\title{
THE EFFECT OF CO-BRANDING STRATEGY, BRAND EQUITY ON PURCHASE INTENTION THROUGH BRAND PREFERENCE
}

\author{
Boy Riznal') \\ boyriznal@gmail.com \\ Universitas Andalas, Padang, Indonesia \\ Syafrizal ${ }^{2}$ \\ ajosyafrizal@gmail.com \\ Universitas Andalas, Padang, Indonesia
}

\begin{abstract}
This study aims to determine and analyze the influence of co-branding strategies, brand equity on brand preference purchase intention on Bhumi Tea. This research is a causative study with quantitative methods. This study uses a non-probability sampling technique with a purposive sampling method, the criteria used are consumers who have not consumed Bhumi tea, but have heard about the Bhumi tea in the amount of 200 people by withdrawal using Hair et.al. The results showed that co-branding strategy had a positive and significant effect on brand equity, brand equity had a positive and significant effect on the brand preference, brand preference had a positive and significant effect on purchase intention, and cobranding strategies had a positive and significant effect on purchase intention while the brand equity has a positive and insignificant effect on purchase intention on Bhumi tea.
\end{abstract}

\section{Keywords: Co-Branding, Brand Equity, Brand Preference, and Purchase Intention}

\section{Introduction}

Over the past few years, brands have become increasingly important. The brand is a marketing tool that is considered important for companies and consumers which are valuable intangible assets that are important for companies to build long-term relationships with consumers (Kolter et al., 2009). One strategy that can be used is to merge brands with other brands or termed cobranding.Over time there have been many companies that practice the cobranding strategy, one of which is a company engaged in the food and beverage industry, namely the tea industry. The reason for the tea industry's co-branding strategy is the high consumption of Indonesian people in consuming tea, this is because tea is one of the plantation products that has an important role both in the national economy and for public health.
PT. MitraKerinci Plantation is one
of the tea plantation companies
domiciled in South Solok Regency West Sumatra originally as one of the tea plantations owned by PT. Perkebunan Nusantara VI Medan in collaboration with PT. Rajawali Nusantara Indonesia with a Joint Venture scheme.Initially the marketing strategy undertaken by PT. MitraKerinci is taking the $\mathrm{B} 2 \mathrm{~B}$ route, but along with the development of time PT. MitraKerinci has the desire to penetrate the retail market by working together or conducting an alliance (co-branding) with PT AngkasaPura Retail which is engaged in retail business lines in the airport environment and trying to open up the latest business opportunities by cooperating with PT MitraKerinci, which is not bene is a subsidiary of PT Rajawali Nusantara Indonesia (Persero) in the field of tea plantations and exports to launch tea products with the Bhumi label 
in the hope of representing the name of Indonesia and is quite accepted internationally.

In addition, this collaboration can also increase Bhumi's brand equity, where high equity will create brand awareness, brand associations, perceived quality, brand loyalty, and other exclusive assets that add value to the product.Thus, the brand will be valued if the brand is promoted to consumers. This has been done by Bhumi tea itself through the biggest event in 2018, the 2018 Asian Games, which was not only a sporting event in various countries, but this opportunity was immediately put to good use by the food and beverage industry, not least in Bhumi tea.

High brand equity can increase the brand preference (brand preference) of a product where the brand preference will affect the brand recognition in the minds of consumers. Brand preference is the last step before consumers make a purchase decision. The tendency of consumers to buy a brand or take action related to the purchase called the purchase intention. In addition, CobbWalgren et al. (1995) states that higher brand equity creates greater purchase intentions. Because brand equity is reflected in brand preferences, it can be concluded that brand preference will be reflected in purchase intentions. Likewise, empirical evidence from researchers for example. Chen \& Chang, 2018; Chang \& Liu, 2010; Tolba\& Hassan, 2010; Moradi\&Zarei, 2011) supports a positive relationship between preferences and purchase intentions.
Based on the background above, we can identify the problems that occur with the problem formulation as follows how does co-branding strategy influence brand equity, How does brand equity influence brand preference, How does brand preference influence purchase intention, How does brand equity influence purchase intention, How does co-branding influence the purchase intention of bhumi tea.

\section{Methods}

This type of research is causative with quantitative methods that use statistical analysis to empirically test the relationships between research variables. Furthermore, the population in this study includes all consumers who will consume Bhumi tea. This study uses a non-probability sampling technique with a purposive sampling method. This sample selection method is by deliberately selecting certain samples and by ignoring other samples, because this particular sample has special characteristics that are not possessed by other samples, namely consumers who have not consumed Bhumi tea, but have heard about tea. The Bhumi. Then, the source of the data needed in this study is primary data with data collection techniques carried out by the questionnaire method.

\section{Operational Definitions of Research Variables}

Operational variables are needed to determine the type, indicator, and scale of the variables involved in the study. Operational variables in this study can be explained in the table below:

Table 1. Operational Definitions of Research Variables

\begin{tabular}{|c|c|c|c|c|}
\hline $\begin{array}{l}\text { Variable } \\
\text { Definition }\end{array}$ & Dimension & Indicator & $\begin{array}{c}\text { Scale } \\
\text { Measurement }\end{array}$ & Source \\
\hline $\begin{array}{l}\text { Purchase } \\
\text { Intention } \\
\text { Purchase } \\
\text { intention can } \\
\text { be defined as } \\
\text { the possibility } \\
\text { for consumers } \\
\text { to buy a }\end{array}$ & - & $\begin{array}{l}\text { 1. Will buy product } X \\
\text { 2. Will seriously consider } \\
\text { buying product } X \\
\text { 3. Very likely to buy product } X \\
\text { 4. Will buy product } X \\
\text { 5. again Recommend } X \\
\text { products } \\
\text { 6. Will make the same choice } \\
\text { on product } X\end{array}$ & Likert Scale & $\begin{array}{c}\text { (Soenyoto, } \\
2015 ; \text { Vinh } \\
\text { \&Huy, 2016) }\end{array}$ \\
\hline
\end{tabular}


ISSN 1412-2936

EISSN 2549-7308

\begin{tabular}{|c|c|c|c|c|}
\hline \multicolumn{5}{|l|}{ product } \\
\hline $\begin{array}{l}\text { Brand } \\
\text { Preference } \\
\text { The extent to } \\
\text { which } \\
\text { consumers like } \\
\text { one brand } \\
\text { over another. }\end{array}$ & - & $\begin{array}{l}\text { 1. Product } X \text { is superior } \\
\text { 2. Prefer product } X \\
\text { 3. Will consider product } X \text { first } \\
\text { 4. Interested in trying product } \\
X \\
\text { 5. Has a very strong } \\
\text { preference on product } X\end{array}$ & Likert Scale & $\begin{array}{c}\text { (Chang \& Liu, } \\
\text { 2009) }\end{array}$ \\
\hline \multirow{4}{*}{$\begin{array}{l}\text { Brand Equity } \\
\text { Brand equity } \\
\text { as a set of five } \\
\text { brand assets } \\
\text { (brand } \\
\text { awareness, } \\
\text { brand } \\
\text { associations, } \\
\text { perceived } \\
\text { quality, brand } \\
\text { loyalty, and } \\
\text { other exclusive } \\
\text { assets) that } \\
\text { add value to a } \\
\text { product. }\end{array}$} & $\begin{array}{c}\text { Brand } \\
\text { Association }\end{array}$ & $\begin{array}{l}\text { 1. Can quickly remember } \\
\text { some of the characteristics } \\
\text { of product } X \\
\text { 2. Can quickly remember the } \\
\text { logo or symbol of product } X \\
\text { 3. can't imagine product } X \text { in } \\
\text { mind }\end{array}$ & \multirow{4}{*}{ Likert Scale } & \multirow{4}{*}{$\begin{array}{c}\text { (Manzoor\& } \\
\text { Shaikh,2016) }\end{array}$} \\
\hline & $\begin{array}{c}\text { Brand } \\
\text { Awareness }\end{array}$ & $\begin{array}{l}\text { 4. Know the product } X \\
\text { 5. Can recognize product } X \\
\text { among competing brands. } \\
\text { 6. Know what product } X \text { looks } \\
\text { like }\end{array}$ & & \\
\hline & $\begin{array}{l}\text { Perceived } \\
\text { Quality }\end{array}$ & $\begin{array}{l}\text { 7. } X \text { product quality is high } \\
\text { 8. The quality of product } X \text { is } \\
\text { very high } \\
\text { 9. Product } X \text { is reliable } \\
\text { 10. Product } X \text { must be } \\
\text { quality }\end{array}$ & & \\
\hline & Brand Loyalty & $\begin{array}{l}\text { 11. Product } X \text { is available } \\
\text { for purchase } \\
\text { 12. Product } X \text { is the first } \\
\text { choice } \\
\text { 13. Loyal to product } X \\
\text { 14. Product } X \text { is one of } \\
\text { the selected brands to be } \\
\text { purchased }\end{array}$ & & \\
\hline \multirow{3}{*}{$\begin{array}{l}\text { Co-Branding } \\
\text { Co-branding is } \\
\text { defined as } \\
\text { pairing two or } \\
\text { more branded } \\
\text { products } \\
\text { (brand } \\
\text { constituents) } \\
\text { to form } \\
\text { separate and } \\
\text { unique } \\
\text { products } \\
\text { (composite } \\
\text { brands), this is } \\
\text { a popular } \\
\text { strategy for } \\
\text { introducing } \\
\text { new products }\end{array}$} & $\begin{array}{l}\text { Brand } \\
\text { Alliance } \\
\text { Evaluation }\end{array}$ & $\begin{array}{l}\text { 1. Very familiar with PT } \\
\text { MitraKerinci - PT } \\
\text { AngkasaPura Retail } \\
\text { 2. Appreciate the collaboration } \\
\text { carried out between PT } \\
\text { MitraKerinci - PT } \\
\text { AngkasaPura Retail }\end{array}$ & Likert Scale & $\begin{array}{c}\text { (Bucklin \& } \\
\text { Sengupta,2013) }\end{array}$ \\
\hline & $\begin{array}{l}\text { Relationships } \\
\text { Perceived } \\
\text { from Brand } \\
\text { Alliances }\end{array}$ & $\begin{array}{l}\text { 3. } \text { Cooperation made makes } \\
\text { sense } \\
\text { 4. Have a relationship } \\
\text { between each. } \\
\text { 5. Feel a match if they work } \\
\text { together }\end{array}$ & \multirow[t]{2}{*}{ Likert Scale } & \multirow[t]{2}{*}{$\begin{array}{c}\text { (Bucklin \& } \\
\text { Sengupta,2013) }\end{array}$} \\
\hline & $\begin{array}{l}\text { Expected } \\
\text { Feelings of } \\
\text { Brand }\end{array}$ & $\begin{array}{l}\text { 6. Not surprised by the } \\
\text { collaboration } \\
\text { 7. Hope that they work }\end{array}$ & & \\
\hline
\end{tabular}


ISSN 1412-2936

EISSN 2549-7308

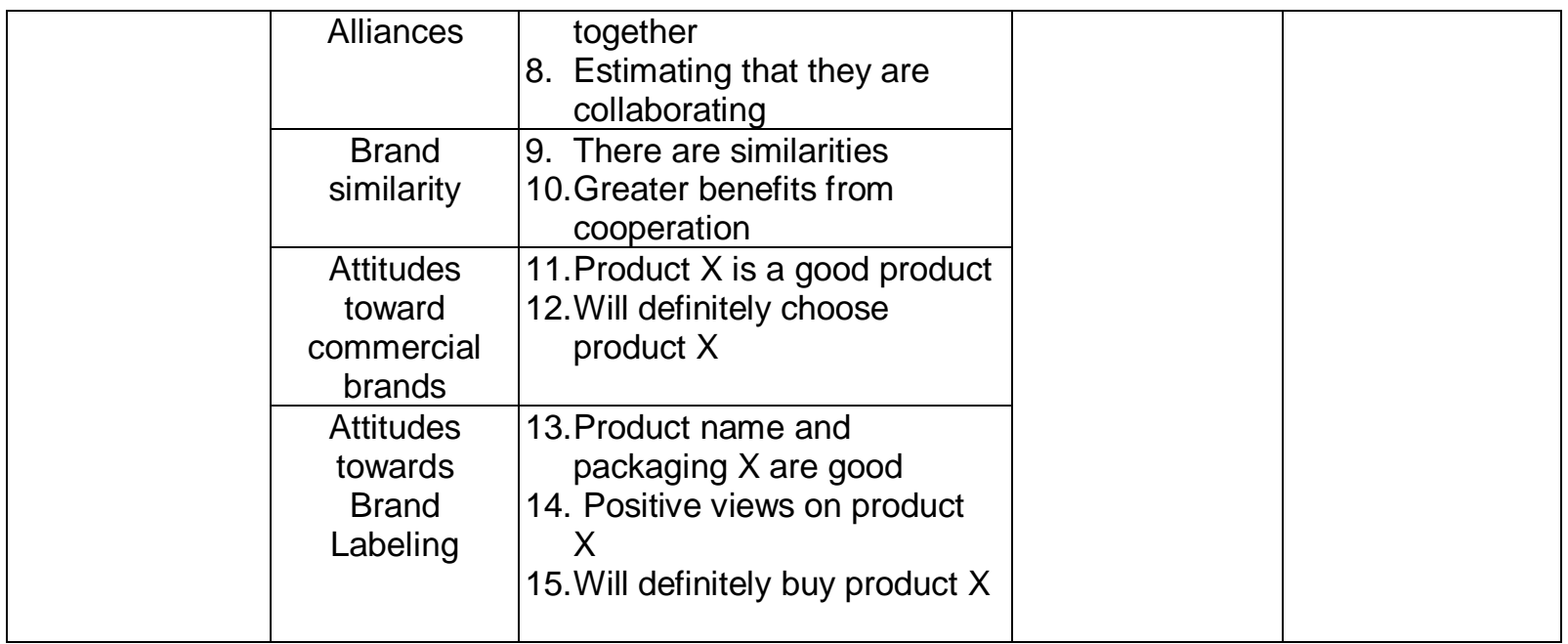

\section{Data analysis}

In accordance with the formulation of the problem above, then in this study first carried out measurements of the model (outer model), the structure of the model (inner model) and hypothesis testing with the Structural Equation Modeling (SEM) approach using SmartPLS software version 3.00.

\section{Results and Discussion \\ Description of Respondent Demographics}

Questionnaires of distributed, 200 respondents or all samples responded to the questionnaire by filling in directly. Based on these data it is known that the response rate of the respondents in this study was $100 \%$. This proves that consumers are very cooperative in this study.

From the results of the questionnaire it can be seen that the respondents who are female are the most interested in consuming Bhumi Tea as much as $54 \%$ while the rest are respondents who are male by $46 \%$. Most of the respondents are 26-30 years old with a percentage of $32 \%$ and have completed college education at $70 \%$ with marital status in general being married with a percentage of $77 \%$. In general, consumers who will consume Bhumi tea have income per month between the range of $6,000,000-10,000,000$ with a percentage of $39.5 \%$ with jobs as employees of BUMN / BUMS. Then consumers prefer to consume tea in one time per day, this is an initial capital for tea producers that in general consumers like to consume tea and moreover for bhumi tea consumers like the green ginger variant because the variant has more health benefits compared to with other variants.

\section{Testing the Measurement Model (Outer Model) Convergent Validity}

This test is carried out to see which indicators are best used to measure each variable in other words to see the validity of each indicator. The high value of the loding factor indicates that the indicator does indeed explain the variable it is measuring. Indicators that have a factor loading value $>0.7$ are said to be valid indicators (Yamin and Kurniawan, 2011: 202) and vice versa if below that value it will be eliminated in the research model. The results of data processing using SmartPLS 3.0 produce outer loading which can be seen in the table below.

Table 2. Results of Outer Loading

\begin{tabular}{|l|r|l|l|l|}
\hline & Brand Equity & Brand Preference & Co-Branding & Purchase Intention \\
\hline BE01 & 0.903 & & & \\
\hline
\end{tabular}


ISSN 1412-2936

EISSN 2549-7308

\begin{tabular}{|c|c|c|c|c|}
\hline BE02 & 0.880 & & & \\
\hline BE03 & 0.881 & & & \\
\hline BE04 & 0.896 & & & \\
\hline BE05 & 0.639 & & & \\
\hline BE06 & 0.882 & & & \\
\hline BE07 & 0.907 & & & \\
\hline BE08 & 0.911 & & & \\
\hline BE09 & 0.874 & & & \\
\hline BE10 & 0.880 & & & \\
\hline BE11 & 0.884 & & & \\
\hline BE12 & 0.803 & & & \\
\hline BE13 & 0.830 & & & \\
\hline BE14 & 0.885 & & & \\
\hline BP01 & & 0.859 & & \\
\hline BP02 & & 0.908 & & \\
\hline BP03 & & 0.870 & & \\
\hline BP04 & & 0.933 & & \\
\hline BP05 & & 0.939 & & \\
\hline $\mathrm{CO01}$ & & & 0.808 & \\
\hline $\mathrm{CO02}$ & & & 0.842 & \\
\hline $\mathrm{COO3}$ & & & 0.860 & \\
\hline COO4 & & & 0.784 & \\
\hline CO05 & & & 0.850 & \\
\hline CO06 & & & 0.657 & \\
\hline CO07 & & & 0.849 & \\
\hline CO08 & & & 0.637 & \\
\hline CO09 & & & 0.868 & \\
\hline CO10 & & & 0.832 & \\
\hline C011 & & & 0.829 & \\
\hline CO12 & & & 0.772 & \\
\hline C013 & & & 0.746 & \\
\hline C014 & & & 0.764 & \\
\hline C015 & & & 0.736 & \\
\hline PI01 & & & & 0.919 \\
\hline PI02 & & & & 0.888 \\
\hline PI03 & & & & 0.938 \\
\hline PI04 & & & & 0.911 \\
\hline PI05 & & & & 0.792 \\
\hline PI06 & & & & 0.827 \\
\hline
\end{tabular}

Source: Smart PLS 3.0 Processed Results

Based on the table above it can be seen that invalid indicators consist of $\mathrm{BE} 05, \mathrm{CO06}$, and $\mathrm{CO} 08$ this is caused by the outer loading value of the indicator under 0.70 . Then the invalid indicators will be eliminated in the model and the model is calculated again. After recalculating, the outer loading value is above 0.70 , thus, all indicator variables are valid.

\section{Internal Consistency Test}

To find out the extent to which these variables have an accuracy and accuracy of measurements that are consistent over time, a reliability test is performed. Instrument reliability in this study was measured by two criteria, namely the value of composite reliability and Cronbach's alpha. The composite reliability and Cronbach's alpha values of all study variables must be $>0.7$.

Table 3.Reliability Test Results 
ISSN 1412-2936

EISSN 2549-7308

\begin{tabular}{|l|c|c|c|}
\hline & $\begin{array}{c}\text { Cronbach's } \\
\text { Alpha }\end{array}$ & $\begin{array}{c}\text { Composite } \\
\text { Reliability }\end{array}$ & Keterangan \\
\hline Brand Equity & 0.975 & 0.978 & Reliability \\
\hline Brand Preference & 0.943 & 0.956 & Reliability \\
\hline Co-Branding & 0.959 & 0.963 & Reliability \\
\hline Purchase Intention & 0.941 & 0.954 & Reliability \\
\hline
\end{tabular}

Source: Smart PLS 3.0 Processed Results

The table above shows that all variables have composite reliability and Cronbach's alpha values above 0.70 , which means that the research variables are considered good and reliable to be used as input in the process of analyzing data whose purpose is to test the research hypothesis.

\section{Discriminant Validity Test}

This test is done to see how big the difference between variables. The value seen in this test is the average variance extracted (AVE) value obtained as an estimation result where the value must be $>0.50$ which can be seen in the Table below.

Table 4. Construct Validity Results

\begin{tabular}{|l|c|}
\hline & Average Variance Extracted (AVE) \\
\hline Brand Equity & 0.773 \\
\hline Brand Preference & 0.814 \\
\hline Co-Branding & 0.665 \\
\hline Purchase Intention & 0.776 \\
\hline
\end{tabular}

Source: Smart PLS 3.0 Processed Results

From the table above it can be seen that the AVE value of all variables has fulfilled the requirements where all variables have the AVE value above 0.5. Furthermore, the condition that must also be fulfilled is the square root value of AVE for each variable must be greater than the correlation value with other variables. If the AVE square root value of each construct is greater than the correlation value between the construct and other constructs in the model, it is said to have a good discriminant validity value.

Table 5. Value of Discriminant Validity

\begin{tabular}{|l|r|r|r|r|}
\hline & Brand Equity & Brand Preference & $\begin{array}{c}\text { Co- } \\
\text { Branding }\end{array}$ & $\begin{array}{c}\text { Purchase } \\
\text { Intention }\end{array}$ \\
\hline Brand Equity & 0.879 & & & \\
\hline Brand Preference & 0.925 & 0.902 & & \\
\hline Co-Branding & 0.853 & 0.789 & 0.815 & \\
\hline Purchase Intention & 0.866 & 0.858 & 0.891 & 0.881 \\
\hline
\end{tabular}

Source: Smart PLS 3.0 Processed Results

In the table above it can be seen that the comparative value of AVE roots shows that each of these values is greater than the correlation between other variables. So it can be concluded that all latent variables have good discriminant validity and construct validity.

Inner Model (Structural Model)

\section{R Square Test}

Structural Model Evaluation of the reflexive indicator measurement model using $R$ square. Changes in the value of $R$ square can be used to assess the effect of certain independent latent variables on the dependent latent variable whether it has a substantive effect. The structural evaluation model values can be seen in Table 6 below. 
ISSN 1412-2936

EISSN 2549-7308

Table 6. R Square Test Results

\begin{tabular}{|l|c|c|}
\hline & R Square & R Square Adjusted \\
\hline Brand Equity & 0.728 & 0.726 \\
\hline Brand Preference & 0.855 & 0.854 \\
\hline Purchase Intention & 0.857 & 0.855 \\
\hline
\end{tabular}

Source: Smart PLS 3.0 Processed Results

Based on the table above it can be seen that the $R$ square value of brand equity is 0.728 which can be interpreted that brand equity is influenced by the cobranding strategy of $72.8 \%$ while the remaining $27.2 \%$ is explained by other variables outside this study. Then the value of $R$ square brand preference is 0.855 which can be interpreted that brand preference is influenced by brand equity is $85.5 \%$ while the remaining $14.5 \%$ is explained by other variables outside this study and the $\mathrm{R}$ square purchase intention value is 0.857 which can be interpreted that purchase intention is influenced by brand preference is $85.7 \%$ while the remaining $14.3 \%$ is explained by other variables outside this study.

\section{Hypothesis Testing (t test)}

Hypothesis testing is done by running the Bootstrapping algorithm on SmartPLS to determine whether the hypothesis is accepted or rejected. The hypothesis in this study uses two tailed tests, the rule of thumb is a significance level of $10 \%$ (t statistics 1.65), a significance level of $5 \%$ (t statistics 1.96) and a significance level of $1 \%$ (t statistics 2.57). So it can be concluded that the hypothesis is accepted when the significance level is less than 0.05 or the $t$-value exceeds the critical value of 1.96 (Hair et al., 2014). Then, the t value and significance value in this study can be seen in the table path coefficient.

Table 7. Result OfPath Coefficient

\begin{tabular}{|c|c|c|c|c|c|c|}
\hline & $\begin{array}{c}\text { Original } \\
\text { Sample } \\
(\mathrm{O})\end{array}$ & $\begin{array}{c}\text { Sample } \\
\text { Mean } \\
(\mathrm{M})\end{array}$ & $\begin{array}{c}\text { Standard } \\
\text { Deviation } \\
(\text { STDEV })\end{array}$ & $\begin{array}{c}\text { T Statistics } \\
(|\mathrm{O} / \mathrm{STDEV}|)\end{array}$ & $\begin{array}{c}\mathrm{P} \\
\text { Values }\end{array}$ & Information \\
\hline $\begin{array}{c}\text { Brand Equity -> } \\
\text { Brand Preference }\end{array}$ & 0.925 & 0.924 & 0.011 & 85.528 & 0.000 & Accepted \\
\hline $\begin{array}{c}\text { Brand Equity -> } \\
\text { Purchase Intention }\end{array}$ & 0.031 & 0.022 & 0.086 & 0.363 & 0.717 & Rejected \\
\hline $\begin{array}{c}\text { Brand Preference -> } \\
\text { Purchase Intention }\end{array}$ & 0.390 & 0.396 & 0.084 & 4.662 & 0.000 & Accepted \\
\hline $\begin{array}{c}\text { Co-Branding -> } \\
\text { Brand Equity }\end{array}$ & 0.853 & 0.854 & 0.016 & 53.503 & 0.000 & Accepted \\
\hline $\begin{array}{c}\text { Co-Branding -> } \\
\text { Purchase Intention }\end{array}$ & 0.557 & 0.559 & 0.058 & 9.661 & 0.000 & Accepted \\
\hline
\end{tabular}

Source: Smart PLS 3.0 Processed Results

\section{Effect of Co-Branding Strategies on Brand Equity in Bhumi Tea}

The analysis shows that the cobranding strategy has a positive effect on brand equity, meaning that high brand equity is built by creating brand alliances. Furthermore, these results also provide empirical evidence that there is a significant relationship between the two. The level of significance means that brand alliance (co-branding) has an important role to increase brand equity in TehBhumi.

This can be seen in the results of the descriptive analysis stating that the alliance carried out between PT MitraKerinci and PT AngkasaPura Retail 
is in a pretty good category this can be seen in the perceived relationship of the brand alliance which in general PT MitraKerinci with PT AngkasaPura Retail have a good relationship between each of them. Thus co-branding has a strong relationship with increasing brand equity, and when they are observed the impact synergizes to increase brand value where Bhumi's tea brand equity is in the good enough category this can be seen in its brand association, meaning that consumers remember everything that is related to the bhumi tea brand, for example, consumers can quickly remember the logo or symbol of the Bhumi tea product.

Then this is also influenced by the demographics of respondents where in general the education taken by respondents is a graduate which means that the respondents in this study are people who are educated so quickly and easily to remember the Bhumi tea product logo and ultimately the brand equity in Bhumi tea be increased. So the results of this study are in accordance with research conducted by Park et al, 2016; Ponnum\&Balaji, 2015; Aqeel, Hanif, \& Malik, 2017; Van et al, 2011 which explains that co-branding has a positive and significant effect on brand equity.

\section{Effect of Brand Equity on Brand Preference on Bhumi Tea}

Building brand equity is very important because it will bring benefits to companies where the high preference of consumers to choose the brand. This is consistent with the results of research that brand equity has a positive effect on brand preference, meaning that consumers will choose the brand if the brand equity they build is high meaning the word is brand equity is the main motive for a consumer to choose the brand. Furthermore, these results also provide empirical evidence that there is a significant relationship between the two. The level of significance means that brand equity has an important role to increase brand preference in TehBhumi.

When seen in the results of descriptive analysis, it is stated that Bhumi's tea brand equity is in a fairly good category, this can be seen in its brand association, meaning that consumers remember everything related to the bhumi tea brand, for example, consumers can quickly remember the logo or symbol of the Bhumi tea product. . This means that consumers capture the Bhumi tea brand strongly so that there will be a higher preference for Bhumi tea, for example consumers are interested in trying Bhumi tea products and have a very strong preference on Bhumi tea. From the demographic table the respondents explained that in general consumers have a high preference for Bhumi tea with Green Ginger flavor variants. The results of this study are in accordance with the study of Chang et al, 2018; Hoeffl\& Keller, 2003; Myers, 2003; Buil et al, 2013; Cobb-Walgren et al 2015; Chang et al, 2018; Tran TrungVinh\& Le Van Huy, 2016; Soenyoto, 2015 that brand equity has a significant impact on brand preferences. Therefore, companies must focus on increasing brand equity to increase brand preference.

\section{Effect of Brand Preference on Purchase Intention on Tea Bhumi \\ The results of this study are} brand preferences have a positive effect on purchase intentions, meaning that it arises the consumer's liking for the brand and encourages consumer intentions to buy the brand. The brand is an important intangible asset that is important to the company, a distinctive tool that builds long-term relationships with consumers, and protects its rights, so the company must be able to create consumers' affection for the brand despite intense competition from other brands. The reason is that there are more brands that enter the market that sell the same product category, consumers have more choice of brands and therefore, the preferred brand will be more likely to be 
chosen by consumers compared to those who do not so it is believed that it will influence consumers' intention to buy a product. Furthermore, these results also provide empirical evidence that there is a significant relationship between the two. The level of significance means that brand preference has an important role to increase buying interest in Bhumi Tea products.

When seen in the results of descriptive analysis states that in general consumers quite like Bhumi tea products where consumers are interested in trying Bhumi tea products and have a very strong preference on the Green Ginger flavor variants that can be seen in the respondents' demographic tables. So consumers are quite interested in consuming Bhumi tea products and will make the same choices on Bhumi tea products with the price of 1 pcs as 35,000 . That way consumers can afford to buy the tea because in general consumers have an income / month of more than $5,000,000$. The results of this study are in accordance with Buil et al 2013; Cobb-Walgren et al., 1995; Chen \& Chang, 2018; Chang \& Liu, 2010; Tolba\& Hassan, 2010; Moradi\&Zarei, 2011; Chernatony, Harris, \&Christodoulides, 2014; Cobb-Walgren et al, 2015; Myers, 2003; Hellier, Geursen, Carr, and Rickard, 2013 who explained that brand preference would be reflected in purchase intentions.

\section{The Influence of Brand Equity on Purchase Intention on Tea Bhumi}

This study provides an empirical analysis that brand equity has a positive effect on purchase intentions, meaning that the more aware and loyal the consumers are to the brand, the more will drive the purchase intention of a product. Furthermore, these results also provide empirical evidence that there is no significant relationship between the two. This means that brand equity does not have an important role in buying interest in Tea Bhumi products.
This can be seen in the consumer loyalty to the Bhumi tea brand where in general consumers have not been loyal to the Bhumi tea brand. This can be seen from consumers who are not loyal in consuming Bhumi tea products, which is evidenced also through consumers not recommending Bhumi tea products to their families and partners caused because the Bhumi Tea brand is hard to find in the market. So the company must be able to increase loyalty to the Bhumi tea brand and the company must be able to overcome it by making a marketing strategy so that consumer interest will arise to consume Bhumi tea.

The results of this study are in accordance with Manzoor\&Shaikh (2016) which provides important implications for marketing managers that the results of the study are contrary to the hypothesis that not all four dimensions of brand equity are found to have a direct and positive influence on consumer purchase intentions. Only perceived quality was found to have a positive direct effect on consumer purchase intentions while the influence of the other three dimensions namely brand association, brand awareness, and brand loyalty was very low or negative.

\section{Effects of Co-Branding Strategies on Purchase Intention on Bhumi Tea}

The analysis shows that the cobranding strategy has a positive effect on purchase intention, meaning that the right co-branding strategy will create purchase interest in a product. Furthermore, these results also provide empirical evidence that there is a significant relationship between the two. The level of significance means that brand alliance (co-branding) has an important role to increase buying interest in TehBhumi.

In general, the cooperation between PT MitraKerinci and PT AngkasaPura Retail is quite good, this can be seen in the dimensions of the perceived relationship of the brand alliance, which means that in general PT 
MitraKerinci with PT AngkasaPura Retail has a good relationship between respectively, because the concept of Cobranding is a popular marketing strategy and is considered an efficient approach to brands so that it will have an impact on company profits and will help improve unknown brands. So it can be concluded that Co-branding is a very important strategy because it will bring profits to the company through the emergence of consumer interest in the brand formed by the Co-branding for example in the Bhumi Tea brand which in general consumers are interested enough to consume Bhumi tea products and will make choices the same for Bhumi tea products and buying Bhumi tea products will thus benefit the company with this strategy.

In addition, the co-branding strategy provides clear benefits and brings expertise from partner brands and increases combined brand equity which helps financially by reducing production and marketing costs, further co-branding reduces investment costs, reduces risk, and provides more returns fast and cobranding helps reduce costs of entering new markets and can increase consumer buying interest. This empirical study is in accordance with Boone, 2017; Hadjicharalambous, 2016; Jevons \&Gabbott, 20015; Strate\&Rappole, 2017; $\mathrm{Lu}$ Yan $\mathrm{Hu}$, \&Zhong $\mathrm{Hu}, 2014$ that successful co-branding requires a detailed understanding of consumer perspectives because their evaluation influences purchase intention.

\section{Conclusions}

The results of this study can be applied as a guideline for developing strategies that are appropriate for business, especially in the tea industry producers or marketers LIKE a company should be able to market Bhumi tea to the most influential relatives in a community, know about the development of Bhumi tea products, and be happy to share stories with colleagues or relatives about things they know about Bhumi tea products so that more people will find out information about Bhumi tea and disseminating this information to other consumers.

The next, companies need to improve the brand so that in the future this Bhumi tea is superior compared to other teas by making attractive product packaging by including important information such as brand, product type, product label, expire date and nutritional content and health benefits provided after drinking Bhumi tea so consumers will know that this product is quality for them and give gifts or promos to loyal customers.

Companies need to improve brand loyalty because it has the lowest average which means that consumers are not loyal to the Bhumi tea brand. This can be seen from consumers who are not loyal in consuming Bhumi tea products. Thus, the way the company does is brand name reflects the products offered, Make a short brand name of maximum 3 syllables whose goal is to keep the brand remembered by consumers, brand names are easy to pronounce, brand names have a relationship with logos, have their own uniqueness, and check the name on search engines so that the brand name is not the same as other company.

Finally, the co-branding strategy that provides the lowest average value can be seen in the dimensions of attitudes towards labeling and attitudes towards packaging, so for that the company can improve it by replacing product packaging that originally used paper packaging now switches to paper packaging. sachet whose purpose is to protect the environment so that no environmental pollution occurs, because the paper packaging has a negative impact on the environment.

\section{Reference}

Ajzen, I. (1991). The theory of planned behaviour.

Organizational 
behavior and human decision processes, 50, 179-211.

American Marketing Association.(2015). Dictionary. Retrieved March 3, 2015, from American Marketing Association: http:// ama. Org / resources/

Pages/ Dictionary.aspx?dLetter=B\&dLett er $=B$

Anderson, J. (2011). Measuring the FInancial Value of Brand Equity: the Perpetuity Perspective. Journal of Business Administration Online, 10(1), 111.

Atilgan, E., Aksoy, S., \&Akinci, S. (2005). Determinants of the brand equity: A verification approach in the beverage industry in Turkey. Marketing Intelligence \& Planning, 23(3), 237-248.

Brooks , G. P., \&Barcikowski, R. S. (2012). The PEAR Method for Sample Sizes in Multiple Linear.Regression. Multiple Linear Regression Viewpoints, 38(2), 1-16.

Buil, I., Martinez, E., \&Chernatony, L. d. (2013). The influence of brand equity on consumer responses. Journal of Consumer Marketing, 30(1), 62-74.

Chen, C. F., \& Chang, Y. Y. (2008). Airline brand equity, brand preference, and purchase intentions-The moderating effects of switching costs. Journal of Air Transport Management, 14(1), 40-42.

Christodoulides, G., \&Chernatony, L. d. (2009). Consumer Based Brand Equity Conceptualization \& Measurement: A Literature Review. International Journal of Market Research.

Cobb-Walgren, C., Ruble, C., \& D, N. (1995). Brand Equity, Brand Preference, Purchase Intention. Jornal of Advertising, 24(3), 2540.

Cooper, D. R., \& Schindler, P. S. (2014). Business Research Method (12 ed.). New York: McGraw-Hill.
Ebrahim, R. (2011). A Study of Brand Preference: An Experiential View. London: Brunel Business School.

Huong, N. T. (2012). Key Factors Affecting Consumer Purchase Intention: A study of Safe Vegetable in Ho Chi Minh City, Vietnam.

Janice , J., \&Leosaputro, J. I. (2014). The Impact of Corporate Image of PT XYZ towards Job Applicant Attraction in Surabaya.iBuss Management, 2(2), 12-20.

Keller, K. L. (1993). Conceptualizing, Measuring, and Managing Customer-Based Brand Equity. Journal of Marketing, 57, 1-22.

Lohmöller, J.-B.(2013). Latent Variable Path Modeling with Partial Least Squares. Berlin: Springer Science \& Business Media.

Madahi, A., \&Sukati, I. (2012).The effect of external factors of purchase intention amongst young generation in Malaysia.International Business Research, 5(8).

Vincze, U. H. (2012). Consumer-based brand equity and top-of-mind awareness: a cross-country analysis. Journal of Product \& Brand Management, 21(6), 439 451. 